Hanna Gloria Christopher ${ }^{1}$

\section{PENGARUH BIMBINGAN KARIR TERHADAP KEMANDIRIAN SISWA DALAM MEMILIH KARIR DI KELAS XI SMK Negeri 1 Ma'u}

\begin{abstract}
Abstrak
Penelitian ini bertujuan untuk mengungkap pengaruh layanan bimbingan karir terhadap kemandirian siswa dalam memilih karir siswa kelas XI SMK Negeri 1 Ma'u. Penelitian ini merupakan penelitian kuantitatif. Sampel penelitian adalah siswa kelas XI SMK Negeri $1 \mathrm{Ma} u$ berjumlah 30 siswa. Penelitian ini menggunakan analisis regresi linear sederhana. Hasil penelitian adalah (1) Berdasarkan hasil perhitungan yang dilakukan untuk seluruh variabel penelitian sebanyak 70 item, uji validitas dan reliabilitas dinyatakan valid dan reliabel, (2) Berdasarkan rata-rata hitung angket penelitian untuk variabel Bimbingan karir adalah 94,53 termasuk dalam kategori sangat tinggi. Rata-rata hitung angket penelitian untuk variabel Kemandirian siswa dalam memilih karir adalah 94,68 termasuk kategori sangat tinggi, (3) Perhitungan koefisien korelasi diperoleh data antara Variabel (X) dan Variabel (Y) menggunakan rumus Korelasi Product Moment sebesar 0,988, (4) Berdasarkan perhitungan uji koefisien korelasi antara dua variabel dengan metode korelasi $\mathrm{r}$ product moment didapat $\mathrm{rxy}=$ 0,988, kemudian dihitung Koefisien determinasi sebesar 97,614\% artinya bahwa antara Bimbingan Karir dengan Kemandirian siswa dalam memilih karir memberikan sumbangan sebesar 97,614, (5) Untuk membuktikan hipotesis penelitian ini maka dilakukan pengujian hipotesis dengan menggunakan uji t satu pihak. Setelah diperoleh nilai $r$ selanjutnya dilakukan perhitungan nilai thitung sebesar 46,832. Nilai thitung dikonfirmasikan dengan nilai ttabel untuk $\mathrm{dk}=(\mathrm{n} 1-1)=55$ pada taraf signifikan 5\% $(\alpha=0,05)$ adalah 2,000. Karena thitung $>$ ttabel yaitu 46,832 > 2.000 maka Ha diterima dan Ho ditolak yang berarti "Ada Pengaruh Bimbingan Karir Terhadap Kemandirian Siswa Dalam Memilih Karir Di Kelas XI SMK Negeri 1 Ma'u”.
\end{abstract}

Kata Kunci: Psikologi pendidikan dan pembelajaran

\begin{abstract}
\footnotetext{
${ }^{1}$ Prodi Bimbingan Konseling, IKIP Gunungsitoli

Alamat email: hannagloria87@gmail.com
}

This study aims to uncover the influence of career guidance services on student independence in choosing the career of a class XI student of SMK Negeri 1 Ma'u. This research is a quantitative research. The sample of this research is 30th grade students of SMK Negeri 1 Ma'u. This research uses simple linear regression analysis. The results of the study are (1) Based on the results of calculations made for all research variables of 70 items, the validity and reliability tests are declared valid and reliable, (2) Based on the average calculation of the research questionnaire for the career guidance variable is 94.53 included in the very category high. The average calculation of the research questionnaire for the variable Independence of students in choosing a career is 94.68 , including very high categories, (3) Calculation of the correlation coefficient 
obtained data between Variables (X) and Variables (Y) using the Product Moment Correlation formula of 0.988, (4) Based on the calculation of the correlation coefficient test between the two variables with the product moment correlation method obtained rxy $=0.988$, then the coefficient of determination is calculated at $97.614 \%$ meaning that between Career Guidance and Independence of students in choosing a career contributes 97,614, (5) To prove the research hypothesis this then testing the hypothesis using a one-party $t$ test. After the $r$ value is obtained, then a t-count value of 46,832 is calculated. The t-count value was confirmed with a table value for $\mathrm{dk}=(\mathrm{n} 1-1)=55$ at a significant level of $5 \%(\alpha=0.05)$ is 2,000 . Because tcount $>$ thable is 46,832> 2,000, Ha is accepted and Ho is rejected, which means "There is an Effect of Career Guidance on Student Independence in Choosing Careers in Class XI of SMK Negeri 1 Ma'u".

Keywords: Educational psychology and learning.

\section{PENDAHULUAN}

Karir merupakan orientasi utama setiap orang/siswa terutama pada siswa Sekolah Menengah Kejuruan. Untuk merencanakan kehidupan karir yang lebih baik, diperlukan suatu bimbingan yang memberikan bekal yang cukup kepada siswa. Bimbingan karir sebagai jembatan bagi siswa untuk mengetahui informasi karir yang ingin ditekuni oleh siswa agar siswa itu sendiri dapat mandiri dalam mengetahui informasi karir yang sesuai dengan kondisi diri siswa. Kemandirian siswa sangat penting, karena mengingat kehidupan karir merupakan kehidupan yang akan dijalani siswa setelah lulus Sekolah Menegah Kejuruan, agar masa karir yang akan dijalani memberikan hasil yang memuaskan. Secara lebih khusus program bimbingan karir diwujudkan di sekolah terutama berperan membantu para siswa dalam memahami dirinya, memahami lingkungan, serta mengembangkan rencana dan kemampuan untuk membuat keputusan yang bermakna bagi masa depannya. Bimbingan karir membantu siswa dalam proses mengambil keputusan mengenai karir atau pilihan utama yang mempengaruhi kehidupannya di masa depan, Hatari dalam Gani (1985: 10). Siswa seharusnya dari awal dapat memahami bahwa karir merupakan suatu jalan hidup yang perlu ditata dan dipersiapkan dengan baik untuk kehidupan di masa yang akan datang, sehingga dapat membekali diri dengan pengetahuan tentang dirinya sendiri, tentang dunia kerja, dan belajar dari pengalaman-pengalaman yang dijalani baik oleh dirinya ataupun orang lain sebagai acuan dalam mengambil keputusan yang sesuai dengan keadaan dirinya (Zagoto, dkk., 2019).

Namun dalam kenyataannya kondisi pelaksanaan bimbingan karir bagi siswa tidak pernah terlaksana dengan baik. Kadang siswa tidak peduli dengan pendidikan yang mereka geluti saat ini dan tidak peduli dengan masa depan karir mereka, sehingga terjadi kekeliruan dan ketidaktepatan dalam mengambil keputusan tentang tujuan kedepan setelah lulus Sekolah Menengah Kejuruan. Masalah-masalah semacam ini sering dihadapi oleh para siswa, terutama menetukan jenis pendidikan manakah yang harus ditempuhnya, serta bagaimana langkah- langkah yang seharusnya ditempuh dalam mempersiapkan dirinya dalam memasuki lapangan kerja di masa yang akan datang. Dari hasil pengamatan sebelumnya yang dilakukan di SMK Negeri 1 Ma'u dan informasi yang diterima dari guru-guru di sekolah tersebut, didapatkan informasi bahwa siswa kebanyakan sulit untuk memilih karir setelah lulus sekolah terutama sekolah mana yang akan dituju, sulit membuat keputusan apakah melanjutkan pendidikannya atau berhenti dan mencari pekerjaan yang sesuai dengan pendidikannya. Siswa setelah lulus belum bisa mandiri dalam menentukan pilihan karirnya, kurang cekatan melihat akan masa depan, bahkan siswa tidak tahu kemampuan yang ada dalam dirinya serta kemampuan lain yang dimilikinya (Zagoto, dkk., 2018; Sarumaha, 2018; Dakhi, O., 2013) 
Adanya peranan yang mendukung perkembangan wawasan atau pengalaman yang luas baik dalam sekolah, lingkungan, orang tua, dan orang lain yang bisa memberikan informasi dalam mencapai keputusan dalam bidang yang dipilih seseorang.

Karir merupakan orientasi utama setiap orang/siswa terutama pada siswa Sekolah Menengah Kejuruan. Untuk merencanakan kehidupan karir yang lebih baik, diperlukan suatu bimbingan yang memberikan bekal yang cukup kepada siswa. Bimbingan karir sebagai jembatan bagi siswa untuk mengetahui informasi karir yang ingin ditekuni oleh siswa agar siswa itu sendiri dapat mandiri dalam mengetahui informasi karir yang sesuai dengan kondisi diri siswa. Kemandirian siswa sangat penting, karena mengingat kehidupan karir merupakan kehidupan yang akan dijalani siswa setelah lulus Sekolah Menegah Kejuruan, agar masa karir yang akan dijalani memberikan hasil yang memuaskan. sehingga para siswa akan berusaha semaksimal mungkin untuk meningkatkan prestasinya, mengembangkan potensi dirinya dan lingkungannya.

Penelitian ini bertujuan untuk melihat apakah ada pengaruh layanan bimbingan karir terhadap kemandirian siswa dalam memilih karir siswa kelas XI SMK Negeri 1 Ma'u. Bimbingan karir merupakan suatu jenis bimbingan yang berusaha membantu individu dalam memecahkan masalah yang ada pada dirinya, mengenal dunia kerja, merencanakan masa depannya, dengan bentuk kehidupan yang diharapkannya untuk menentukan pilihannya, dan mengambil suatu keputusannya tersebut adalah yang paling tepat sesuai dengan keadaan dirinya dihubungkan dengan persyaratan-persyaratan dan tuntutan pekerjaan/karir yang dipilihnya. Layanan informasi merupakan salah satu jenis layanan dalam bimbingan konseling di sekolah yang amat penting untuk membantu peserta didik agar dapat terhindar dari berbagai masalah yang dapat mengganggu terhadap pencapaian perkembangan siswa, baik yang berhubungan dengan diri pribadi, sosial, belajar ataupun karirnya (Hidayati, 2015). Prayitno (2004:23) mengartikan bimbingan sebagai bantuan yang diberikan kepada siswa dalam rangka menemukan pribadi, mengenal lingkungan, dan merencanakan masa depan. Menurut Winkel (2005: 114) berpendapat bahwa:

Bimbingan karir adalah bimbingan dalam mempersiapkan diri menghadapi dunia kerja, dalam memilih lapangan kerja atau jabatan /profesi tertentu serta membekali diri supaya siap memangku jabatan itu, dan dalam menyesuaikan diri dengan berbagai tuntutan dari lapanan pekerjaan yang dimasuki.

Lebih lanjut Hidayati (2015) mengatakan bahwa "Bimbingan karir juga dapat dipakai sebagai sarana pemenuhan kebutuhan perkembangan peserta didik yang harus dilihat sebagai bagaian integral dari program pendidikan yang diintegrasikan dalam setiap pengalaman belajar bidang studi.

Beberapa teori yang mengemukakan tentang pengertian pemilihan karir di antaranya yaitu: Teori Holland dalam Sukardi (1994:72) mengungkapkan bahwa pemilihan jabatan adalah merupakan dari hasil interaksi antara faktor hereditas dengan segala pengaruh budaya, teman bergaul, orangtua, orang dewasa yang dianggap memiliki peranan yang penting. Teori Huppock dalam Sukardi (1994:70) pekerjaan jabatan atau karir yang dipilih adalah jabatan yang diyakini bahwa jabatan itu paling baik untuk kebutuhannya. Pemilihan karier merupakan proses pengambilan keputusan yang berlangsung sepanjang hayat bagi mereka yang mencari banyak kepuasan dari pekerjaannya.

Osipow dalam Kansas (2007), dalam teorinya memandang pilihan karir seseorang dipengaruhi oleh tiga komponen yang mendasar dalam hidup diantaranya : 
a. Pengaruh genetika seseorang adalah warisan dari gen ayah atau ibu, sehingga pada prinsipnya individu memiliki berbagai potensi bawaan yang akan menentukan sifat-sifat, minat, bakat kemampuan lainnya. Pada akhirnya potensi tersebut memiliki pengaruh yang besar dalam kehidupan seseorang terutama dalam pemulihan karir yang akan dilalui pada masa yang akan datang.

b. Pengalaman masa kecil. Berbagai pola asuh yang diterima individu pada masa anak-anak akan mempengaruhi bagaimana pilihan karirnya di masa depan. Salahsatunya pengaruh pendidikan dan pola asuh orang tua terhadap anak, sebagai berikut:

1. Lingkungan keluarga yang mencintai, melindungi dan menuntut secara wajar akan menuntun anak menjadi orang yang memiliki orientasi dimasa kanak-kanak dan orang yang berorientasi dalam pekerjaan yang akan ditempatinya.

2. Lingkungan keluarga yang menolak, mengabaikan dan tidak acuh terhadap anak akan menggiring anak menjadi orang yang tidak memiliki orientasi dalam pekerjaan.

3. Kondisi yang terlalu melindungi (over-protective) atau menuntut terlalu berlebihan akan menjadikan anak tidak memiliki orientasi dalam pekerjaan.

4. Sebagain anak yang berasal dari keluarga yang bersifat menolak kemungkinan orientasinya menjadi mencari kepuasan, dan

5. Lingkungan keluarga yang santai dan mencintai akan memberikan jumlah keterkaitan yang memadai.

c. Kebutuhan-kebutuhan manusia. Kebutuhan-kebutuhan individu dapat mempengaruhi pilihan karier individu tersebut diantaranya, kebutuhan fisik, kebutukan akan rasa aman, kebuhan akan kasih sayang dan cinta, kebuhan penghargaan diri, kebutuhan akan pengetahuan dan pemahaman, kebutuhan estetika, kebutuhan aktualisasi diri, dan kebutuhan hubungan dengan yang kuasa.

Selanjutnya Hartono (2010), menekankan bahwa terdapat enam tingkat dalam karir.

Tingkat tersebut antara lain:

a. Tak terampil, pekerjaan pada tingkat ini tidak membutuhkan keahlian atau pendidikan khusus.

b. Semi terampil, pekerjaan pada tingkat ini telah menuntut adanya keterampilan dan pengalaman khusus, namun belum mensyaratkan adanya kemandirian dan inisiatif yang tinggi dari individu.

c. Terampil, pekerjaan pada tingkatan ini telah menuntut adanya keterampilan dan pendidikan khusus pada individu.

d. Semi professional dan bisnis kecil, pekerjaan pada tingkatan ini telah menuntut adanyatanggung jawab dalam skala rendah dan kebijaksanaan untuk diri sendiri. Individu pada tingkatan ini berpendidikan menengah atas umum atau tekhnologi kejuruan.

e. Professional tingkatan kedua, mensyaratkan adanya kemandirian dan tanggung jawab yang lebih besar serta telah menerapkan sistem manajerial yang baik. Individu yang berada pada tingkatan ini memiliki pendidikan yang baik, yakni berada pada jenjang sarjana hingga master.

f. Profesional tingkatan pertama, secara mandiri telah mampu untuk berkarya cipta dan menerapkan sistem manajerialsecara baik. Pada tingkatan ini telah terbentuk tanggung jawab penuh pada individu untuk mengambil berbagai keputusan dan kebijaksanaan. Individu yang berada pada tingkatan ini memiliki pendidikan yang relatif tinggi dan mapan.

Menurut Ali dan Asrori (2004:119-120), upaya pengembangan kemandirian remaja dilakukan melalui: 
a. Penciptaan partisipasi dan keterlibatan remaja secara penuhdalam keluarga. Dapat diwujutkan dalam bentuk: saling menghargai antar anggota keluarga, keterlibatan dalam memecahkan masalah remaja atau keluarga.

b. Penciptaan keterbukaan, dapat diwujutkan dalam bentuk: toleransi dalam perbedaan pendapat, memberi alasan terhadap keputusan yang diambil, keterbukaan terhadap minat, mengembangkan komitmen terhadap tugasnya, kehadiran dan keakraban hubungan.

c. Penciptaan kebebasan untuk mengekplorasi lingkungan. Dalam diwujudkan dalam bentuk: mendorong rasa ingin tahu remaja, adanya jaminan rasa aman, adanya aturan tetapi tidak cenderung mengancam apabila ditaati.

d. Penciptaan positif tanpa syarat. Dapat diwujutkan dalam bentuk: menerima perbedaan, tidak membedakan teman yang satu dengan yang lainnya, menghargai hasil kerja.

e. Empati terhadap remaja. Dapat diwujudkan dalam bentuk: memahami dan menghayati pikiran dan perasaan remaja, melihat berbagai persoalan remaja dengan menggunakan perspektif atau sudut pandang remaja.

f. Penciptaan kehangatan hubungan dengan remaja. Dapat diwujutkan dalam bentuk: interaksi akrab tetapi menghargai, menambah frekuensi interaksi dan tidak bersikap dingin, membangun suasana humor dan komunikasi ringan dengan remaja.

Dari pendapat di atas disimpulkan bahwa dalam mengembangkan kemandirian perlu juga adanya interaksi yang baik antara pendidik dan anak karena seiring dengan perkembangannya, seorang anak perlahan-lahan melepaskan diri dari ketergantungan pada orang tua atau orang lain sekitarnya dan belajar untuk mandiri. Kemandirian dapat berkembang dengan baik jika diberikan kesempatan untuk berkembang melalui latihan yang dilakukan secara terus menerus dan dilakukan sejak dini. Latihan tersebut dapat berupa pemberian tugastugas tanpa bantuan dan tentu saja tugas-tugas tersebut disesuaikan dengan potensi dan kemampuan siswa. Mengingat kemandirian akan banyak memberikan dampak yang positif bagi perkembangan individu, apalagi dalam hal memilih karir, maka sebaiknya kemandirian diajarkan pada seseorang sedini mungkin sesuai kemampuannya. Latihan kemandirian yang diberikan harus disesuaikan dengan perkembangan usianya dan kemampuannya.

\section{METODE}

Penelitian ini dirancang berdasarkan pokok masalahnya, pokok masalah diformulasikan dalam bentuk pertanyaan penelitian, dan dikumpulkan data-datanya sesuai dengan tujuan. Dari pokok masalah yang telah ditetapkan dirumuskan judul, dibuat latar belakang masalahnya, diidentifikasi masalah-masalahnya. Selanjutnya dari pokok masalah ditentukan jenis data, instrumen pengumpulan data, sumber data dan subjek penelitian, teknik analisis data, dan metode penelitian, yang kesemuanya di uraikan.

Peneliti melakukan penelitian di SMK Negeri 1 Ma'u. dalam pengambilan sampel berdasarkan purposive sampling dimana peneliti memilih sampel berdasarkan kriteria yang ditentukan oleh peneliti, sampel dalam penelitian ini merupakan siswa SMK Negeri 1 Ma'u kelas XI sebanyak 30 orang siswa. Teknik pengumpulan data menggunakan instrument sebanyak 70 item yang nyatakan valid dan reliable sehingga layak digunakan dalam penelitian ini. Berdasarkan hasil analisis peneliti menggunakan uji lineritas data yang merupakan salah sat syarat yang dilakukan untuk melakukan analisis linear sederhana. Apabila data tidak linear maka analisis tidak dapat 
dilanjutkan. Uji linear menggukan $\mathrm{F}$ tes. Uji hipotesis menggunakan regresi linear sederhana yang dilakukan dengan membuat persamaan regresi sederhana dan menguji keberartian dan kelinearan regresi.

\section{HASIL DAN PEMBAHASAN}

Hasil penelitian adalah (1) Berdasarkan hasil perhitungan yang dilakukan untuk seluruh variabel penelitian sebanyak 70 item, uji validitas dan reliabilitas dinyatakan valid dan reliabel, (2) Berdasarkan rata-rata hitung angket penelitian untuk variabel Bimbingan karir adalah 94,53 termasuk dalam kategori sangat tinggi. Rata-rata hitung angket penelitian untuk variabel Kemandirian siswa dalam memilih karir adalah 94,68 termasuk kategori sangat tinggi, (3) Perhitungan koefisien korelasi diperoleh data antara Variabel (X) dan Variabel (Y) menggunakan rumus Korelasi Product Moment sebesar 0,988, (4) Berdasarkan perhitungan uji koefisien korelasi antara dua variabel dengan metode korelasi $\mathrm{r}$ product moment didapat $\mathrm{rxy}=$ 0,988, kemudian dihitung Koefisien determinasi sebesar 97,614\% artinya bahwa antara Bimbingan Karir dengan Kemandirian siswa dalam memilih karir memberikan sumbangan sebesar 97,614, (5) Untuk membuktikan hipotesis penelitian ini maka dilakukan pengujian hipotesis dengan menggunakan uji $\mathrm{t}$ satu pihak. Setelah diperoleh nilai $\mathrm{r}$ selanjutnya dilakukan perhitungan nilai thitung sebesar 46,832. Nilai thitung dikonfirmasikan dengan nilai ttabel untuk $\mathrm{dk}=(\mathrm{n} 1-1)=55$ pada taraf signifikan $5 \%(\alpha=0,05)$ adalah 2,000. Karena thitung $>$ ttabel yaitu 46,832> 2.000 maka Ha diterima dan Ho ditolak yang berarti "Ada Pengaruh Bimbingan Karir Terhadap Kemandirian Siswa Dalam Memilih Karir Di Kelas XI SMK Negeri 1 Ma'u”.

\section{SIMPULAN}

Berdasarkan hasil penelitian ini, maka dapat dinyatakan bahwa ada ada pengaruh layanan bimbingan karir terhadap kemandirian siswa dalam memilih karir siswa kelas XI SMK Negeri 1 Ma'u. Hal ini menunjukkan bahwa kehidupan karir merupakan kehidupan yang akan ditempuh siswa mulai dari siswa itu lahir dan akan dijalani siswa setelah lulus Sekolah Menengah Kejuruan, agar masa karir yang akan dijalani memberikan hasil yang memuaskan. Secara lebih khusus program bimbingan karir diwujudkan di sekolah terutama berperan membantu para siswa dalam memahami dirinya, memahami lingkungan, serta mengembangkan rencana dan kemampuan untuk membuat keputusan yang bermakna bagi masa depannya. Bimbingan karir membantu siswa dalam proses mengambil keputusan mengenai karir atau pilihan utama yang mempengaruhi kehidupannya dimasa depan.

\section{DAFTAR PUSTAKA}

Abdul, Ruslan, Gani, 1985, Bimbingan Karir, Tarsito, Bandung.

Arikunto, Suharsimi, 2006, Prosedur Penelitian, Rineka Cipta, Jakarta.

Dakhi, O. "Aplikasi Pendeteksian Kerusakan File Akibat Virus Dengan Menggunakan Metode Heuristic." Pelita Informatika Budi Darma, vol. 4, no. 1, pp. 35-41, 2013.

Dakhi, O. 2013. Belajar Javascript Dengan Mudah Dan Detail. Jakarta: Dapur Buku. pp. 1-202. Depdiknas, 2007, Penataan Pendidikan Profesional Konselor dan Layanan Bimbingan dan Konseling dalam Jalur Pendidikan Formal, Depdiknas, Jakarta.

Hidayati, Richma, 2015, Layanan Informasi Karir Membantu Peserta Didik Dalam Meningkatkan Pemahaman Karir, FKIP Universitas Muria Kudus, Jurnal Konseling GUSJIGANG, Vol. 1 No. 1 Tahun 2015 ISSN 2460-1187. 
Mulyaningtyas Renita B. dan Hadiyanto Purnomo Yusup, 2006, Bimbingan dan Konseling untuk SMA/MA Kelas XI, Esis, Yogyakarta.

Prayitno. 2004. Layanan Bimbingan dan Konseling. Padang: Universitas Negeri Padang.

Hidayati, 2015. Dasar-dasar Bimbingan dan Konseling, Rineka Cipta, Jakarta.

Sarumaha, R., Harefa, D., \& Zagoto, Maria M. (2018). Upaya Meningkatkan Kemampuan Pemahaman Konsep Geometri Transformasi Refleksi Siswa Kelas XII-IPA-B SMA Kampus Telukdalam Melalui Model Pembelajaran Discovery Learning Berbantuan Media Kertas Milimeter. Jurnal Education and development, Vol.6 No.1, 90-96. https://doi.org/10.37081/ed.v6i1.668

Subana, 2001, Dasar-dasar Penelitian Ilmiah, Pustaka Setia, Bandung.

Sugiyono, 2009, Prosedur Penelitian, Alfabeta, Bandung.

Sukardi, Dewa Ketut, 2004, Psikologi Pemilihan Karir, Rineka Cipta, Jakarta.

Suparno Paul, 2003, Pendidikan Budi Pekerti untuk SMA/SMK, Kanisius.

Tim Penyusun, 2011, Pedoman Penulisan Skripsi, Edisi Kelima, IKIP Gunungsitoli, Gunungsitoli.

Winkel, W. S. dan Hastuti, 2005, Bimbingan dan konseling di Institusi Pendidikan, Media Abadi, Jakarta.

Hartono, 2010, Pelaksanaan Bimbingan Karir, (online), (http://www.kompasiana.com. diakses 2 Januari 2018).

Lamman, Spencer dan Kass 2007, Kemandirian dalam Belajar, (online) (http://www.cantique.blongspot.com. diakses 24 Januari 2018).

Anne Roe, 1956, BK karir, (online). (http:/bkpemula.wordpress.com. diakses 19 Februari 2018).

S., Mamat dan Nandang B, 2000, Bimbingan Karir di SMK, (online) (http://file.upi.edu, diakses 2 Juni 2012).

Zagoto, Maria M., Yarni, Nevi; Dakhi, O. (2019). Perbedaan Individu dari Gaya Belajarnya Serta Implikasinya Dalam Pembelajaran. Jurnal Review Pendidikan dan Pengajaran, 2(2), 259265.

Zagoto, Maria M. \& Dakhi, O (2018). Pengembangan Perangkat Pembelajaran Matematika Peminatan Berbasis Pendekatan Saintifik Untuk Siswa Kelas XI Sekolah Menengah Atas. Jurnal Review Pendidikan dan Pengajaran, 1(1), 157-170.

Zagoto, Maria M. (2018). Pengembangan Perangkat Pembelajaran Matematika Berbasis Realistic Mathematic Educations Untuk Siswa Kelas V Sekolah Dasar, Jurnal Education And Development, vol. 3, no. 1, p. 53, Feb. 2018. https://doi.org/10.37081/ed.v3i1.139 